\title{
Influence of Corporate Governance on the Extent of Corporate Social Responsibility and Environmental Reporting
}

\author{
Naser Benomran (Corresponding author) \\ Accounting Department, School of Maritime Business and Management \\ University Malaysia Terengganu (UMT) \\ Tel: 0060-111-429-2979 E-mail: naser19640@yahoo.com \\ Mohd Hassan Che Haat \\ Accounting Department, School of Maritime Business and Management \\ University Malaysia Terengganu (UMT) \\ +609-6684188 E-mail: Hassan@umt.edu.my
}

Hafiza Binti Hashim

Accounting Department, School of Maritime Business and Management

University Malaysia Terengganu (UMT)

+609-6683427 E-mail: hafizaaishah@umt.edu.my

Nor Raihan Binti Mohamad

Accounting Department, School of Maritime Business and Management

University Malaysia Terengganu (UMT)

+609-6684188 E-mail: raihan@umt.edu.my

Received: April 16, 2015

Accepted: April 29, 2015 Published: June 24, 2015

doi:10.5296/jee.v6i1.7442

URL: http://dx.doi.org/10.5296/jee.v6i1.7442 


\section{Abstract}

This study examines the influence of corporate governance on the extent of corporate social responsibility and environmental reporting (CSER) in Libyan companies according to legitimacy theory, using quantitative and qualitative methods. The variables used in this study are government ownership, chief executive officer duality, board independence, and board size. The study was conducted in Libya because this country has a unique political and economic system. Moreover, the regime in Libya has influenced the nature of CSER, as has Islamic factor. The quantitative data consist of 162 annual reports derived from 42 Libyan companies. The qualitative data are obtained from 31 financial and information managers from the largest Libyan companies, who expressed their perceptions regarding the influence of the study variables on the extent of CSER. Results confirm that corporate governance generally has no influence on the extent of CSER in Libyan companies, with the exception of board size.

Keywords: Corporate Social Responsibility and Environmental Reporting; Libya, legitimacy theory 


\section{Introduction}

Studies have examined the influence of corporate governance on the extent of corporate social responsibility and environmental reporting (CSER) to understand the influence of corporate governance on CSER. Studies on corporate governance and CSER are rarely conducted in emerging economies (Khan, Muttakin, \& Siddiqui, 2012; Judge, Douglas, \& Kutan, 2008) is a significant research gap because of at least two significant limitations: First, no known study has used mixed methods to examine the influence of corporate governance on CSER. Second, studies on the influence of corporate governance on CSER have focused on developed countries. Therefore, the results of these studies have varied in terms of the positive and negative influences of corporate governance on CSER. Thus, the current study examines previous research on this topic. It also extracts quantitative data on corporate governance and on CSER from the annual reports of a sample that consists of Libyan companies. Moreover, it gathers data from public relations and financial managers through interviews.

\section{Literature Review and Study Framework}

Corporate social responsibility has been defined in various ways by different authors. For instance, Mohr, Webb, and Harris (2001) described it as "a company's commitment to minimizing or eliminating any harmful effects and maximizing its long-run beneficial impact on society". Noyer (2008) defined Corporate Social Responsibility (CSR) as:

"CSR is a concept whereby financial institutions not only consider their profitability and growth, but also the interests of society and the environment by taking responsibility for the impact of their activities on stakeholders, employees, shareholders, customers, suppliers, and civil society represented by Non Government Organizations (NGOs)".

Many researchers provide evidence to define corporate governance, for example, Koh (2001)

"...the process and structure used to direct and manage the business and affairs of the corporation with the objective of enhancing long-term value for shareholders and financial viability of the business". p. 23 .

The definition that was provided by the Malaysian High Level Finance Committee for Corporate Governance (Committee, 1999):

"Corporate governance is the process and structure used to direct and manage the business and affairs of the company towards enhancing business prosperity and corporate accountability with the ultimate objective of realizing long-term shareholders value, whilst taking into account the interests of other stakeholders". p. 52.

Moreover, CSER can be improved through effective corporate governance, in which the responsibility of a company toward society and the environment can be enhanced through the suitable disclosure of CSER by strong managers (Zairi, 2000; Shahin \& Zairi, 2007). Literature provides evidence that corporate governance influences corporate reporting (Shayuti, Chris, \& David, 2009). For instance, Haniffa and Cooke (2005) reported that firms disclose little information when the number of nonexecutive directors is high. Furthermore, companies with concentrated ownership are not highly motivated to disclose much information on their CSER activities (Reverte, 2009). By contrast, Fama and Jensen (1983) determined that the presence of a large number of outside directors monitors management 
well. That is, diffused ownership encourages management to increase the level of CSER and satisfy owners. Ownership is considered to be an important factor in determining the quantity of CSER (Hassan, 2010).

In addition, social and environmental disclosure has been confirmed as an element of good corporate governance (Ontario Security Commission, 2002). The United Nations Global Compact's Report (2004) is concerned with the corporate social responsibility and governance issues that can have a material effect on the financial performance of a company. This recent report is one of many that study the relations between corporate social responsibility and governance practices. The level and nature of convergence between corporate governance and corporate social responsibility has been debated (Strandberg, 2005). The Cadbury Report (1992) pointed out that high-quality corporate governance is reflected in the quality of corporate social responsibility during development. Nonetheless, studies in this area remain lacking despite the significance of corporate governance and its potential influence on the participation of firms in CSER. Hence, no conclusion can be drawn about the influence of corporate governance on the extent of CSER outcomes (Elmogla, 2009).

The framework of legitimacy theory has been applied by many researchers (Ahmad, 2004; Deegan, 2002; Deegan \& Rankin, 1996) to companies that are "sensitive" toward social and environmental issues. According to Deegan and Rankin (1996), legitimacy theory posits that CSER disclosure practices are responsive to political, social, and economic pressures. Reverte (2009) also examined the determinants of corporate social responsibility in listed firms in Spain, with emphasis on the influence of factors that are relevant to legitimacy theory in relation to corporate social responsibility. Legitimacy theory is the most commonly cited theory in social and environmental reporting studies (Gray, Kouhy, \& Lavers, 1995). Furthermore, Tilling (2004) believes that this theory facilitates the development of a powerful mechanism for understanding voluntary social and environmental disclosure by companies. The theory is based on the notion of a "social contract" that limits the activities of a company within societal constraints. According to Gray, Owen, and Adam (1996), a company obtains support from stakeholders and continues to exist as long as its activities are beneficial or are at least not harmful to society. "Legitimacy" is said to exist as long as the activities of a company are congruent with societal expectations. Thus, a company should voluntarily disclose its environmental accountability to the public in the absence of any mandatory reporting.

Legitimacy theory consists of the following two basic ideas: firms must legitimize their activities, and this legitimacy process benefits the firms somewhat. The first element is consistent with the argument that CSER is linked to social pressure. In addition, the need for legitimacy is unequal across firms because of the differences in the levels of social pressure encountered by firms and in the degrees of responses to this pressure. These factors are determined by a number of elements that are potential determinants of CSER. The second element shows that firms can expect to benefit from achieving legitimacy through CSER. Therefore, legitimacy theory explains both the consequences and determinants of CSER (Hassan, 2010). Figure 1 depicts the theoretical framework examined in the current study, which is based on legitimacy theory. With reference to the framework, this study examines the effect of corporate governance (as independent variables) on the CSER (as dependent variables). This study samples 42 firms and implies that legitimacy theory is most relevant to the explanation of CSER practices. The next section discusses how this study is conducted and explains the development of the hypotheses derived from the theoretical 
framework.

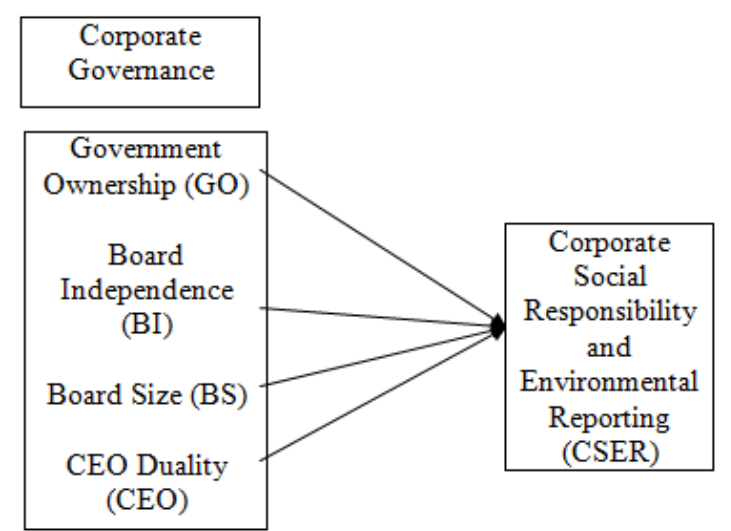

Figure 1, Framework

\section{Hypothesis Development}

\subsection{Government Ownership}

The results of this study support the improvement of corporate governance, thus increasing the level of disclosure. They are consistent with those of the study conducted by Chau and Gray (2002). Private owners are mostly concerned with earning profit and not with CSER issues. By contrast, governments are interested in promoting CSER programs (Mazurkiewicz, 2006); therefore, government-owned companies are highly involved in corporate social responsibility activities because they are conscious of the surrounding communities (Ndemanga \& Koffi, 2009).

In addition, Cormier and Gordon (2001) determined that large government-owned companies in Canada disclose more CSER information than privately owned companies do, as outlined in legitimacy theory. In most countries, ownership is the element that most significantly increases the level of corporate social disclosure (Belal \& Owen, 2007). Furthermore, the results of Ndemanga and Koffi (2009) indicated that government-owned companies assist in preserving corporate social responsibility more than companies with spread ownership do. Previous studies collated various comments concerning the influence of ownership and the extent of CSER; for instance, that government ownership positively influences the corporate social level in Malaysian firms (Amran \& Devi, 2007; Ghazali, 2007). The findings of Said, Zainuddin and Haron (2009) indicate that government ownership is positive influence on the extent of corporate social responsibility. Thus, the influence of government ownership is positive and significantly on the level of disclosure of CSER. On the other hand, some research found a negative influence of ownership on CSER, For instance, the results of Shamsul Nahar, Raihan \& Mokhtar (2011) revealed that government-linked companies do not have influence on the extent of corporate social responsibility disclosure. Thus, it is sensible to reach the following hypothesis:

H1: Government ownership positively influences the extent of CSER. 


\subsection{Board Independence}

The board of directors is important in corporate governance, is responsible for firm management, and is directly responsible for making and implementing corporate decisions (Weir, 2001). The current study focuses on nonexecutive independent and non independent directors instead of executive ones. The majority of the previous studies that investigated the links between corporate governance and CSER indicate that board independence is an important variable (Kilani, 1988; Mashat, Ritchie, Lovatt, \& Pratten, 2005; Saleh, 2001). In addition, independent directors represent the interests of other stakeholders; thus, they influence CSER considerably (Haniffa \& Cooke, 2005). Nonetheless, the findings of previous studies on board independence vary. Some studies determined that this variable has a significant positive influence on the extent of corporate social responsibility and voluntary disclosure (Khan et al., 2012; Eugene, Cheng, Stephen, \& Courtenay, 2006; Fama \& Jensen, 1983; Harjoto \& Jo, 2011; Ho \& Wong, 2001; Norita \& Shamsul-Nahar, 2004). By contrast, Barako, Hancock, and Izan (2006), Eng and Mak (2003), and Gul and Leung (2004) reported the negative influence of board independence on the extent of corporate disclosure. Therefore, another hypothesis of the current study is as follows:

\section{H2: Board independence positively influences the extent of CSER.}

\subsection{Board Size}

The Commercial Code in Libya does not mention the size of the firm board. This variable is left to the General Assembly. The board size recommended by the regulations of the Libyan Stock Market (Corporate Governance Code) is between 3 and 11 members, and the majority of the board should be composed of non-executive directors (Larbsh, 2010). With respect to corporate governance, most government-owned companies have a 10-member board of directors (US Report, 2011). The findings of Hassan (2010) indicate that board size is significantly correlated with the level of CSER. Moreover, the variation in the numbers of directors on the board produces different levels of CSER. These results confirm that a large board can increase the disclosure of CSER. By contrast, previous studies negatively linked board size to the extent of CSER disclosure. Moreover, Halme and Huse (1997) did not observe a relationship between the number of board members and CSER. Therefore, our hypothesis is as follows:

\section{H3: Board size positively influences the extent of CSER.}

\subsection{CEO Duality}

Chief executive officer (CEO) duality occurs when the chairman of the board also acts as the CEO of the company. The dual functions of the CEO and of the chairman must be separated as per corporate governance aims to ensure the independence of the board of directors (Chaganti, Mahajan, \& Sharma, 2007). Agrawal and Chadha (2005) emphasized that if a CEO holds the position of chairman in "CEO duality," then the influence of this executive may limit the effectiveness of the board of directors in managing the company. In addition, managers are important in that they guarantee the achievement of CSER endeavors (Nelson, 1998; Zairi, 2000). Adams (2002) demonstrated that internal elements are factors that 
influence corporate social responsibility. These elements generally include the identities of the managers. Consequently, the role of CEO duality in guiding a company toward CSER is extremely important. By contrast, Gul and Leung (2004) revealed that CEO duality is related to a low disclosure level; thus ensuring the independence of the board to increase disclosure by separating the chairman and CEO duties. The following hypothesis is proposed to test this statement:

H4: CEO duality negatively influences the extent of CSER.

\section{The Research Methods}

Method The objective of the current study is to examine, understand, and explain the influence of corporate governance on the extent of CSER in different sectors (manufacturing, banking, insurance, services, engineering, and oil companies). The present study employed quantitative and qualitative approaches. The quantitative approach was used to examine the annual reports of companies between 2006 and 2012 and determine the influence of corporate governance on the extent of CSER in Libyan companies. The content of texts was categorized and analyzed systematically.

This study categorized and analyzed textual content systematically. The indices of the Egyptian Institute of Directors, Standard \& Poor's, and CRISIL (S\&P/EGX ESG, 2010) were used for CSER. Specifically, the Egyptian Index was the first index in Arabic World to categorize CSER activities into four groups (environment, employee information, community investment, and customer and product) for Arabian countries. The CSER of each category was analyzed based on the number of sentences and a "yes/no" or "1, 0" scoring methodology. The subcategories acquired a score of 1 if information on the items was available and a score of 0 if no information was disclosed. The aggregate score for each company was determined by summing up the scores of 1 (Al-Tuwaijri, Christensen, \& Hughes, 2004).

The qualitative methods supported the quantitative ones, deepened understanding, and facilitated the application of the quantitative results to support the qualitative results (Creswell, 2009). Interviews are the most commonly used method in qualitative studies (Bryman \& Bell, 2004). It is a data collection method in which the beliefs and thoughts of selected participants regarding a particular issue are determined (Collis \& Hussey, 2003). The qualitative approach used in previous studies (Walker, 1985; Judd, Smith, \& Kidder, 1991) elicits information on important related issues through face-to-face interviews and provides the interviewees with space for discussion. The interview questions in the current study were specially designed by the researcher and were guided by the review of literature on CSER practices. Interviews were conducted between March 2013 and June 2013 with a total of 31 public relations and financial managers from 31 sampled companies in different sectors. Seven interviewees (23\%) were financial managers and $24(77 \%)$ were public relations managers. Each interview lasted between 60 and $90 \mathrm{~min}$, and responses were recorded in notebooks and through tape recorders. These interviews enabled the researchers to deepen their understanding of the important issues examined in the present study. Finally, the mixed methods generated significant results and avoided social bias (Gorard \& Taylor, 2004; Johnson \& Onwuegbuzie, 2004; Kreuger \& Neuman, 2006). In addition, this study analyzed 
the content of annual reports to generate quantitative research data.

\subsection{Sample and Data Collection}

The objective of this study is to examine, understand, and explain the effects of corporate governance on the extent of CSER in different sectors (manufacturing, banking, insurance, services, engineering, and oil companies). Quantitative and qualitative research methods were used to collect and analyze data. In the current study, the qualitative methods supported the quantitative methods, deepened understanding, and facilitated the application of the quantitative results to support the qualitative results. The public relations and financial managers of Libyan companies were interviewed to enhance the validity of the data gathered via qualitative research.

The sample represented six different sectors, which were in turn based on the classification generated by the Libyan Public Control Office. These sectors were manufacturing, banking, insurance, services, engineering, and oil companies. They were selected for this study because they are considered the most important sectors in Libya (Mashat, 2005). The final sample (population) for the current study included 42 Libyan companies across these sectors (see Table 1). Specifically, it was composed of 12 (29\%) manufacturing, 11 (26\%) banking, 4 $(10 \%)$ insurance, 1 (2\%) services, 2 (4\%) engineering, and 12 (29\%) oil companies.

Table 1. Summary of Companies, Sectors and Annual Reports

\begin{tabular}{lrrrr}
\hline Sectors & Companies & Percentage & Annual Reports & Percentage \\
\hline Manufacture & 12 & $29 \%$ & 20 & $13 \%$ \\
Services & 1 & $2 \%$ & 5 & $3 \%$ \\
Engineering & 2 & $4 \%$ & 2 & $1 \%$ \\
Insurance & 4 & $10 \%$ & 15 & $9 \%$ \\
Oil & 12 & $29 \%$ & 73 & $45 \%$ \\
Banks & 11 & $26 \%$ & 47 & $29 \%$ \\
Total & 42 & $100 \%$ & 162 & $100 \%$ \\
\hline
\end{tabular}

Data from a six-year period (2006 to 2012) were analyzed quantitatively. The annual reports used in this study were collected from company Web pages and/or by visiting the offices of firms. The current study also categorized and analyzed textual content. The corporate governance and extent of CSER were derived from the annual reports through in this manner (Bayoud, 2012). The current study gathered information for the qualitative analysis through face-to-face interviews with public relations and financial managers. The information collected from literature reviews was used to formulate common questions for the interviewees. A total of 31 managers were interviewed to determine their individual perceptions regarding the influence of corporate governance on the extent of CSER in Libyan companies. The data gathered from interviews with 4 public relations and 27 financial managers (see Table 2). 
Table 2. Sample Profiles of Interviewees

\begin{tabular}{lrrrr}
\hline Sector Name & $\begin{array}{c}\text { Financial } \\
\text { Managers }\end{array}$ & $\begin{array}{r}\text { Public } \\
\text { Relations } \\
\text { Managers }\end{array}$ & Total & Percent \\
\hline Manufacturing & 2 & 7 & 9 & $(29 \%)$ \\
Services & 1 & 0 & 1 & $(3 \%)$ \\
Banks & 1 & 10 & 11 & $(36 \%)$ \\
Insurance & 1 & 2 & 3 & $(10 \%)$ \\
Engineering & 1 & 0 & 1 & $(3 \%)$ \\
Oil & 1 & 5 & 6 & $(19 \%)$ \\
Total & 7 & 24 & 31 & $(100 \%)$ \\
Participation rate & $23 \%$ & $77 \%$ & & $100 \%$ \\
\hline
\end{tabular}

\subsection{Empirical Model}

Multivariate regression was utilized to explain and measure the degree of linkages among variables (Hair et al., 2006). This study applied the following regression model in the Statistical Package for the Social Sciences (SPSS) program to examine the influence of corporate governance on the extent of CSER, as indicated in the following hypothesis:

$$
\mathrm{CSER}=\mathrm{a}+\mathrm{B} 1 \mathrm{GO}+\mathrm{B} 2 \mathrm{BI}+\mathrm{B3} \mathrm{BS}+\mathrm{B} 4 \mathrm{CEO}+e
$$

Where: CSER refers to corporate social responsibility and environmental reporting and is measured either by determining the number of sentences or by classifying "yes/no" or " 1,0 " as dependent variable. GO refers to government ownership. It has a value of " 1 " if the government owns more than $50 \%$ of the shares and " 0 " otherwise. BI refers to board independence and is measured by determining the proportion of independent nonexecutive directors to the total number of directors on the board of the company. BS refers to board size and is measured by counting the total number of directors in the company. CEO refers to CEO duality and is dichotomous, with a value of " 1 " if the roles of the chairman and CEO are combined and " 0 " if otherwise. e is the error term, and B denotes the coefficient of the independent variables.

\subsection{Analysis of the Interview}

The qualitative data were analyzed in two steps. First, the interview transcripts were classified by researchers into similar or different answers (Bayoud, 2012). Second, substantial points were identified, and these points were then classified into two main contexts (Gillham, 2000). In addition, the first analysis process assigned a code to each transcript, and all of the transcripts were reviewed more than once by researchers (Bayoud, 2012). Then, the authors reviewed the tapes and transcripts to determine any information that was not emphasized (Kamla, 2007). Furthermore, the researchers derived a set of categories that were distinguished by statement headings (Gillham, 2000). This process was repeated more than once to ensure that no categories and headings were missed (Hanafi, 2006). A sheet was used as a matrix for each question to classify answers based on the headings (Gillham, 2000). In addition, the researchers transcribed the entire interview to obtain the statements of the interviewees (Gillham, 2000). To transcribe the data, the author categorized the interview 
content into two groups based on similar or different responses (Gillham, 2000). The first analysis process assigned a code to each transcript. Then, the researchers used a large sheet as a matrix. The matrix sheets were classified according to heading and category (Bayoud, 2012).

\section{Results}

\subsection{Quantitative Results}

\subsubsection{Descriptive Analysis}

Table 3 presents the descriptive statistics of all of the variables, including the study population. The investigated Libyan companies contained between 14 and 40 independent directors. Boards also consisted of a minimum of four members and a maximum of nine. The scores of the types of industry and of CEO were either 1 or 0.

Table 3. Main Score and Variation of Data of each Study Variable

\begin{tabular}{lclll}
\hline Variable & Mean & Std. Dev. & Min & Max \\
\hline GO & 0.660494 & 0.47501 & 0 & 1 \\
BI & 26.94136 & 5.890667 & 14 & 40 \\
BS & 6.783951 & 1.140552 & 4 & 9 \\
CEO & 0.882716 & 0.317909 & 0 & 1 \\
CSER & 4.654321 & 10.37994 & 0 & 1 \\
\hline
\end{tabular}

GO: refers to government ownership, BI: refers to board independence, BS: refers to board size, CEO: refers to CEO duality.

\subsubsection{Correlation Analysis}

The Pearson's correlation coefficients of the influence of corporate governance on the extent of CSER are presented in Table 4. The correlations between some independent variables and the CSER indices were significant and positive. Moreover, the correlation coefficient of government ownership with CSER is positive at 0.242 at a p-value (significance level) $<0.05$. Similarly, the correlation coefficient of board independence with CEO duality is positive at 0.30 . In addition, board size is positively correlated with CEO duality at 0.324 , and CEO duality is positively correlated with CSER at 0.165 .

Table 4. Pearson's Correlation Coefficients

\begin{tabular}{llllll}
\hline $\begin{array}{l}\text { Variable } \\
\text { S }\end{array}$ & GO & BI & BS & CEO & $\begin{array}{l}\text { CSE } \\
\text { R }\end{array}$ \\
\hline GO & 1 & & & & \\
BI & $-0.027-$ & 1 & & & \\
BS & $-0.045-$ & $-0.051-$ & 1 & & \\
CEO & $-0.060-$ & $0.301^{* *}$ & $0.324 * *$ & 1 & \\
CSER & $0.242^{* *}$ & 0.020 & $-0.030-$ & $0.165^{*}$ & 1 \\
\hline
\end{tabular}

**Correlation is significant at the 0.01 level; *Correlation is significant at the 0.05 level. 


\subsubsection{Multivariate Regression Analysis}

This study examined three models, namely, pooled Ordinary Least Squares (OLS), fixed effect, and random effect models (see Appendices 1 and 2). The authors used the Hausman specification test to determine the compatibility of either the random or the fixed effect model with this work. The Breusch-Pagan or Lagrangian multiplier test was conducted to determine the presence of random effects and whether to apply the pooled or the random model. The Hausman test results showed the coefficients common to both models, as well as the estimated difference between these models. Thus, this test was significant, and the random effect model was used in this study (see Table 5). Social scientists apply the value of 0.05 as the criterion for statistical significance. Therefore, some factors significantly influenced the extent of CSER as per the observed significance value of less than 0.05. When board size increases by one member, CSER disclosure increases by 2.333962, with $p=0.016$. Thus, H3 is supported. Government ownership, board independence, and CEO duality positively but insignificantly influenced the extent of CSER (4.522, $\mathrm{p}=0.297 ; 0.073218, \mathrm{p}=0.8$; and $1.538926, \mathrm{p}=0.763$; respectively). Furthermore, considerable government ownership is significantly associated with low levels of CSER disclosure by the sampled companies. Thus $\mathrm{H} 1, \mathrm{H} 2$, and $\mathrm{H} 4$ are not supported.

Table 5. Results of Random Effect Model

\begin{tabular}{lllll}
\hline Variables & Coef & $\begin{array}{l}\text { Std. } \\
\text { Err. }\end{array}$ & T & p \\
\hline GO & 4.522 & 4.339 & 1.04 & 0.297 \\
BI & 0.073 & 0.288 & 0.25 & 0.8 \\
BS & 2.333 & 0.970 & 2.4 & 0.016 \\
CEO & 1.538 & 5.092 & 0.3 & 0.763 \\
R $^{2}$ & 0.205 & & & \\
\hline
\end{tabular}

GO refers to government ownership, BI refers to board independence, BS refers to board size, CEO refers to $\mathrm{CEO}$ duality.

\subsection{Qualitative Results}

\subsubsection{Influence of Government Ownership on the Extent of CSER}

In this section, we obtained the perceptions of managers regarding the influence of government ownership on the extent of CSER. Some interviewees emphasized that some Libyan companies remain controlled by the government; in fact, the Libyan government owns more than $50 \%$ of shares in these firms. Moreover, stakeholders cannot influence the policies of government-owned companies. By contrast, the majority of stakeholders can affect disclosure policies in private firms. Some financial managers mentioned that the ownership structures of firms negatively influence the importance of disclosure and its expected benefits. In addition, the interviewees generally agreed that government ownership has no effect on the extent of CSER disclosure in the Libyan context. Twenty-one managers 
$(68 \%)$ believe that this effect does not exist. Furthermore, the managers believe that government ownership is not linked to the extent of CSER disclosure, as provided in the following comment:

"There is no doubt that government ownership affects the extent of social and environmental activities by negative influence".

One manager stated that the private firms in the stock market report a higher level of disclosure than public companies do regardless of age, size, and industry type because these firms seek to satisfy the requirements of stakeholders, who consider the reporting of information on social and environmental activities in the annual reports of a firm to be highly beneficial to financial performance and to the increase in revenues. In addition, investors and employees prefer to work in Libyan companies that often disclose CSER activities; however, these results do not support the research hypothesis discussed in the third section, which relates to this issue and emphasizes a positive influence between government ownership and the extent of CSER. By contrast, these findings are consistent with the quantitative results, which indicated that government ownership is either unrelated to the extent of CSER or the effect is insignificant in Libyan companies.

\subsubsection{Influence of Board Independence on the Extent of CSER}

Expressed opinions differed significantly, but most interviewees observed that board independence did not influence the extent of CSER in Libyan companies. In addition, this variable did not influence the extent of CSER in Libya. The interviewees noted that board independence does not contribute to the importance of CSER activities and its disclosure in the Libyan context. Therefore, these findings support the quantitative results of this study, which indicated that board independence did not influence the extent of CSER in Libyan companies. However, these results do not support the research hypothesis discussed in the third section, which relates to this issue and emphasizes the positive influence of board independence on the extent of CSER.

\subsubsection{Influence of Board Size on the Extent of CSER}

The majority of the interviewees believe that board size can influence the extent of CSER disclosure by a firm. Fifteen (48\%) of the interviewees noted that the board size of Libyan firms can definitely be influenced by a high level of CSER disclosure. Furthermore, 14 of the interviewees $(45 \%)$ believe that this effect is increasingly positive when board size is related to a certain level of CSER. By contrast, only two financial managers $(6 \%)$ believe that board size influences the extent of CSER in theory, but not necessarily in practice. Three managers $(10 \%)$ indicated that board size likely has no effect on the extent of CSER disclosure in Libyan companies. These results are consistent with the research hypothesis, which postulates that board size positively influences the extent of CSER. Therefore, the findings indicate that the qualitative data are consistent with the quantitative results in this respect.

\subsubsection{Influence of CEO Duality on the Extent of CSER}

Opinions regarding the influence of CEO duality on the extent of CSER disclosure vary, but 
most interviewees agreed that this effect is insignificant in Libya. Five (16\%) of the financial managers believe that CEO duality does not affect the extent of CSER disclosure. In addition, $10(32 \%)$ of the public relations managers stated that CEO duality in Libyan companies does not influence the extent of CSER. Therefore, they generally agreed that this effect did not exist. Furthermore, four (13\%) managers believe that CEO duality does not influence the extent of CSER. By contrast, seven (23\%) managers believe that this effect did exist. Moreover, three (10\%) financial managers believe that CEO duality positively influences the extent of CSER disclosure in Libyan companies. The qualitative data results showed that CEO duality has no influence on the extent of CSER. Hence, they are consistent with the quantitative results. These findings are also consistent with the research hypothesis discussed in the third section, which postulated that CEO duality negatively influences the extent of CSER disclosure in Libyan companies.

\section{Conclusion}

\subsection{Influence of Government Ownership on the Extent of CSER}

The analysis results indicated that government ownership has no influence on the extent of CSER. The qualitative findings showed that government ownership does not influence the extent of CSER in Libyan companies. These results also support the quantitative study conducted in this research. Thus, government ownership negatively affects the extent of environmental and social activities in Libyan companies. Meanwhile, the majority of the stakeholders can affect disclosure policies in private firms. This finding contradicts legitimacy theory. From this perspective, Cormier and Gordon (2001) argued that government-owned companies depend more on political and social support than private companies do. Similarly, Tsang (1998) revealed that government-owned banks disclosed less corporate social responsibility information than private banks did in his study on Portuguese banks. Moreover, the survey findings of Mashat et al. (2005) suggest that a significant proportion of the participants were not excited about the idea of collaborating with the public sector to guarantee social responsibility. In addition, Sun, Tong and Tong, (2002) and Kathryn, Dewenter and Malatesta (2001) revealed that public ownership is less efficient than private ownership is. A number of studies support these findings and reported either no relationship (Halme \& Huse, 1997; Leung \& Horwitz, 2004; Nagar, Nanda and Wysocki, 2003) or a negative relationship (Hossain, Lin \& Adams, 1994) between ownership and CSER. By contrast, numerous studies detected the positive influence of government ownership on the extent of CSER. For instance, Cormier and Gordon (2001) reported that government-owned companies disclose more social information than private companies do in the Canadian context. However, the quantitative and qualitative data results from the current study do not support the research hypothesis, which indicates that government ownership positively influences the extent of CSER. Nonetheless, the qualitative data results support the quantitative data findings.

\subsection{Influence of Board Independence on the Extent of CSER}

The existence of independent directors was expected to enhance the disclosure of company information, which is an expectation supported by Rosenstein and Wyatt (1990). In addition, 
the Malaysian Code on Corporate Governance (2007) revealed that the presence of an independent director results in increased voluntary disclosure of information by firms. Moreover, Adam and Hossain (1998) determined a significant positive relationship between the proportion of independent directors and voluntary disclosure. The presence of independent directors on corporate boards also improves the quality of disclosure (Forker, 1992; Chen \& Janggi, 2001; Buniamin, Alrazi, Johari, \& Abd Rahman, 2008). Khan et al. (2012) and Eugene et al. (2006) observed a relationship between board independence and voluntary disclosure. However, some previous studies suggested that board independence is not an important variable and that it is not linked to CSER. Said, Zainuddin, and Haron (2009) did not detect a significant relationship between board independence and the disclosure of corporate social responsibility activities. Abdullah, Mohamad, and Mokhtar (2011) attributed this insignificant relationship to the fact that board independence is not vital to decisions regarding the disclosure of corporate social responsibility in Malaysian companies (Shazrul \& Mazlina, 2013). As per the analysis of the quantitative and qualitative data results, board independence negatively influences the extent of CSER in Libyan companies. Nonetheless, the findings from previous studies support the quantitative and qualitative data results of the current study, which postulate that board independence did not influence the extent of CSER in the Libyan context. However, these results do not support the research hypothesis that infers the positive influence of board independence on the extent of CSER.

\subsection{Influence of Board Size on the Extent of CSER}

We expected that board size may affect the extent of social and environmental activities of companies given that Abdullah et al. (2011) revealed the influence of board size on the level of social disclosure. The quantitative results of the current study showed that board size significantly and positively influences the extent of CSER in Libyan companies. This finding indicates that the greater the number of board members, the higher the tendency of companies to disclose more CSER activities in their annual reports. Moreover, the findings of Hassan (2010) indicate that board size has a significant relationship with the level of CSER. The variation in the number of directors on the board produces different levels of CSER as well. This finding confirms that a large board can increase the level of CSER. By contrast, previous studies negatively linked board size and CSER disclosure. Halme and Huse (1997) observed no significant relationship between board size and environmental disclosure. In addition, Eugene et al. (2006) obtained a similar result for voluntary and environmental disclosures. These results are consistent with the research hypothesis. In addition, the qualitative and quantitative data results indicated the positive influence of board size on the extent of CSER.

\subsection{Influence of CEO Duality on the Extent of CSER}

CEO duality increases the tendency of a company to report on CSER. The result is consistent with those of the previous studies conducted by Ho and Wong (2001), Eugene et al. (2006), and Barako et al. (2006), who observed no relationship between CEO duality and CSER. However, these findings disagree with those of the studies conducted by Gul and Leung (2004) and Forker (1992), who determined that the separation of roles significantly increases 
the amount of disclosure. In addition, Khan et al. (2012) and Eugene et al. (2006) detected the relationship of board independence and CEO duality with voluntary disclosure. These results are consistent with the research hypothesis. Moreover, the qualitative and quantitative data results showed that CEO duality has no influence on the extent of CSER. Finally, the quantitative and qualitative results of the current study revealed that corporate governance generally does not influence the extent of CSER in Libyan companies, with the exception of board size.

\section{References}

Abdullah, S., Mohamad, R., \& Mokhtar, M. (2011). Board independence, ownership, and CSR of Malaysia large firms. Corporate Ownership \& Control, 8(2). Retrieved from http://www.virtusinterpress.org/IMG/pdf/COC_Volume_8_Issue_2_Winter_2011_Continue d4_.pdf\#page $=63$

Adam, M., \& Hossain, M. (1998). Managerial discretion and voluntary disclosure: Empirical evidence from the New Zealand life insurance industry. Journal of Accounting and Public Policy, 17, 245-281. http://dx.doi.org/10.1016/S0278-4254(98)10003-0

Adams, CA. (2002). Organisational factors influencing corporate social and ethical reporting. Accounting. Auditing and Accountability Journal, 15(2), 223-250. http://dx.doi.org/10.1108/09513570210418905

Agrawal, A. and Chadha, S. (2005). Corporate governance and accounting scandals. Journal of Law and Economics, 48(2). Retrieved from http://www.jstor.org/discover/10.1086/430808?uid=3738672\&uid=2\&uid=4\&sid=211057641 88813

Ahmad, N. (2004). Corporate Environmental Disclosure in Libya: Evidence and Environmental Determinism Theory. Unpublished PhD thesis, Napier University, Edinburgh.

Al-Tuwaijri, S. Christensen, T., \& Hughes, K. (2004). The relations among environmental disclosure, Environmental performance, and economic performance: a simultaneous equations approach, Accounting, Organizations and Society, 29(5-6), 447-71. http://dx.doi.org/10.1016/S0361-3682(03)00032-1

Amran, A., \& Devi, S. (2007). Corporate social reporting in Malaysia: A political theory perspective. Malaysian Accounting Review, 6(1). Retrieved from http://eprints.uitm.edu.my/4199/1/J_MARv6n10702.pdf

Belal, A., \& Owen, D. (2007). The views of corporate managers on the current state of, and future prospects for, social reporting in Bangladesh: An engagement-based study. Accounting, $\begin{array}{llll}\text { Auditing and Accountability } & \text { Journal, }\end{array}$ http://dx.doi.org/10.1108/09513570710748599

Barako, D., Hancock, P., \& Izan, H. (2006). Relationship between corporate governance attributable and voluntary disclosures in annual reports: The Kenyan Experience. Financial Reporting, Regulation and Governance. Retrieved from 
https://business.curtin.edu.au/local/docs/1.CtempGWViewerFRRaG_2006_5-1_Refereed_Ba rako_Hancock_Izan.pdf

Bayoud, N. (2012). Corporate Social Responsibility Disclosure and Organizational Performance: The Case of Libya, A Mixed Methods Study. Unpublished PhD Thesis, University of Southern Queensland.

Bryman, A., \& Bell, E. (2004). Business research methods, Oxford University Press, Oxford.

Buniamin, S., Alrazi, B., Johari, N., \& Rahman, A. N. (2008). An investigation of the association between corporate governance and environmental reporting in Malaysia. Asian Journal of Business and Accounting., 1(2), 65-88. ISSN 1985-4064. Retrieved from http://umrefjournal.um.edu.my/filebank/published_article/409/Vol1(2)-Article4.pdf

Cadbury Report (1992). Report of the Committee on the Financial Aspects of Corporate Governance. Gee, London.

Chaganti, R., Mahajan, V., \& Sharma, S. (2007). Corporate board size composition and corporate failures in retailing industry. Journal of Management Studies, 22(4), 400-417. http://dx.doi.org/10.1111/j.1467-6486.1985.tb00005.x

Chau, G., \& Gray, S. (2002). Ownership structure and corporate voluntary disclosure in Hong Kong and Singapore. The International Journal of Accounting, vol. 37, no. 2, pp. 247-265. http://dx.doi.org/10.1016/S0020-7063(02)00153-X

Chen, C., \& Jaggi, B. (2001). Association between independent non- executive directors, Family control and financial disclosures in Hong Kong. Journal of Accounting and Public Policy, 19(4), 285-310. http://dx.doi.org/10.1016/S0278-4254(00)00015-6

Collis, J., \& Hussey, R. (2003). Business Research: a Practical Guide for Undergraduate and Postgraduate Students. 2td ed. Basingstoke: Palgrave Macmillan.

Cormier, D., \& Gordon, I. (2001). An examination of social and environmental reporting strategies. Accounting, Auditing and Accountability Journal, 14. ISSN: 0951-3574. http://dx.doi.org/10.1108/EUM0000000006264

Creswell, J. W. (2009). Research Design: Qualitative, Quantitative and Mixed Methods Approaches. 2nd ed, Los Angeles: Sage Publications, Inc.

Deegan, C. (2002). Introduction the legitimising effect of social and environmental disclosure - a theoretical foundation. Accounting, Auditing and Accountability Journal, 15(3), 282-311. http://dx.doi.org/10.1108/09513570210435852

Deegan, C., \& Rankin, M. (1996). Do Australian companies report environmental news objectively? An analysis of environmental disclosures by firms prosecuted successfully by the environmental protection authority. Accounting, Auditing and Accountability Journal, 9(2), 50-67. http://dx.doi.org/10.1108/09513579610116358

S\&P/EGX ESG Index, "Egyptian Institute of Directors, Standard and Poor's, \& Crisil" (2010). Retrived on July, 2014, from http://www.egx.com.eg/english/homepage.aspx 
Elmogla, M. (2009). Corporate Social Reporting in a Transition Economy: The Case of Libya. Unpublished PhD Thesis, University of Huddersfield.

Eng, L., \& Mak, T. (2003). Corporate governance and voluntary disclosure. Journal of $\begin{array}{llll}\text { Accounting } \text { and Public 22(4), } & \text { 325-345. }\end{array}$ http://dx.doi.org/10.1016/S0278-4254(03)00037-1

Eugene, C., Cheng, Stephen, M., \& Courtenay (2006). Board composition, regulatory regime and voluntary disclosure. International Journal of Accounting, 41(3). http://dx.doi.org/10.1016/j.intacc.2006.07.001

Fama, E., \& Jensen, M. (1983). Separation of ownership and control. Journal of Law and Economics, 26(2). Retrieved from http://www.jstor.org/discover/10.2307/725104?uid=3738672\&uid=2\&uid=4\&sid=211067712 89033

Forker, R. (1992). Corporate governance and disclosure quality. Accounting and Business Research, 22(86), 111-124. http://dx.doi.org/10.1080/00014788.1992.9729426

Ghazali, M. (2007). Ownership structure and corporate social responsibility disclosure: some Malaysian evidence. Corporate Governance: The international journal of business in society, 7(3), 251-266. http://dx.doi.org/10.1108/14720700710756535

Gillham, B. (2000). The Research Interview, Continuum. London.

Gorard, S., \& Taylor, C. (2004). Combining Methods in Educational and Social Research. London: Open Univ Press.

Gray, R., Kouhy, R., \& Lavers, S. (1995). Corporate social and environmental reporting - a review of the literature and a longitudinal, study of UK disclosure. Accounting, Auditing and Accountability Jornal, 8(2), 47-77. http://dx.doi.org/10.1108/09513579510146996

Gray, R. Owen, D., \& Adam, C. (1996). Accounting and Accountability. London; Prentice Halls Inc..

Gul, A., \& Leung, S. (2004). Board leadership, outside directors' expertise and voluntary corporate disclosures. Journal of Accounting and Public Policy, 23(5), 351-379. http://dx.doi.org/10.1016/j.jaccpubpol.2004.07.001

Halme, M., \& Huse, M. (1997). The influence of corporate governance, industry and country factors on environmental reporting. Scandinavian Journal of Management, 13(2), 137-157. http://dx.doi.org/10.1016/S0956-5221(97)00002-X

Hanafi, R. (2006). An Exploration of Corporate Social and Environmental Disclosure in Egypt and the UK: a Comparative Study. University of Glasgow, UK. Retrieved from http://theses.gla.ac.uk/ 1536/1/2006hanafiphd.pdf

Haniffa, R., \& Cooke, T. (2005). The impact of culture, and governance on corporate social reporting. Journal of Accounting and Public Policy, vol. 24, pp. 391-430. http://dx.doi.org/10.1016/j.jaccpubpol.2005.06.001 
Harjoto, M., \& Jo, H. (2011). Corporate governance and CSR nexus. Journal of Business Ethics, 100(1), 45-67. Retrieved from http://bschool.pepperdine.edu/about/people/faculty/appliedresearch/content/harjoto1.pdf

Hassan, N. T. (2010). Corporate Social Responsibility Disclosure:an Examination of Framework of Determinants and Consequences. Unpublished PhD thesis, Durham University. Durham E-Theses.

Ho, M., \& Wong, S. (2001). A study of the relationship between corporate governance structure and the extent of voluntary disclosure. Journal of International Accounting, Auditing and Taxation, 10(2), 139-156. http://dx.doi.org/10.1016/S1061-9518(01)00041-6

Hossain, M., Lin M., \& Adams M. (1994). Voluntary Disclosure in an Emerging Capital Market: Some Empirical Evidence from Companies Listed on the Kuala Lumpur Stock Exchange. The International Journal of Accounting 29, 334-351.

Johnson, R., \& Onwuegbuzie, A. J. (2004). Mixed methods research: A research paradigm whose time has come. Educational Researcher, 33, 1-14. http://dx.doi.org/10.2307/2392366.

Judd, CM, Smith, E. R., \& Kidder (1991). Research Methods in Social Relations, Rinehart and Winston, Fort Worth.

Judge, W., Douglas, J., \& Kutan, A. (2008). Institutional antecedents of corporate governance legitimacy. Journal of Management, 34(4), 765-785. Retrieved from http://jom.sagepub.com/content/early/2008/04/29/0149206308318615.short

Kamla, R. (2007). Critically appreciating social accounting and reporting in the Arab Middle East: a postcolonial perspective. Advances in International Accounting, 20(1), 105-77. http://dx.doi.org/10.1016/S0897-3660(07)20005-4

Kathryn, L., Dewenter, K., \& Malatesta, P. (2001). State-owned and privately owned firms: An empirical analysis of profitability, leverage, and labor intensity. The American Economic Review, 91, 320-334. Retrieved from http://www.jstor.org/stable/2677913

Khan, M., Muttakin, \& Siddiqui, J. (2013). Corporate governance and corporate social responsibility disclosures: evidence from an emerging economy. Journal of Business Ethics, 114(2). Retrieved from http://link.springer.com/article/10.1007/s10551-012-1336-0

Kilani, K. (1988). The Evolution and Status of Accounting in Libya. Unpublished PhD Thesis, University of Hull. UK.

Koh, N. (2001). 3R's of Corporate Governance: Responsibilities, Risks and Reforms. Malaysian Institute of Corporate Governance, Kuala Lumpur.

Kreuger, L. W., \& Neuman, W. L. (2006). Social work research methods: Qualitative and quantitative applications. Boston, MA: Allyn and Bacon.

Larbsh, M. (2010). An Evaluation of Corporate Governance Practice in Libya: Stakeholders' Perspectives. Unpublished PhD Thesis, Nottingham Trent University. 
Leung, S., \& Horwitz, B. (2004). Director ownership and voluntary segment disclosure, Hong Kong evidence. Journal of International Financial Management and Accounting, 15(3), 235-260. http://dx.doi.org/10.1111/j.1467-646X.2004.00109.x

Malaysian Code on Corporate Governance, "MCCG" (2007). Kuala Lumpur: Malaysian Law Journal Sdn Bhd.

Malaysian High Level Finance Committee (1999). Malaysia.

Mashat, A. (2005). Corporate Social Responsibility Disclosure and Accountability (the Case of Libya). PhD thesis. Manchester Metropoltan University, UK.

Mashat, A., Ritchie, B., Lovatt, C., \& Pratten, J. (2005). The social role of accounting: views and perceptions of the accounting community in Libya towards corporate social responsibility and accountability. Paper presented at the Business Studies and the Environment Conference, University of Leeds. UK. Retrieved from http://hdl.handle.net/2173/6771

Mazurkiewicz, P. (2006). Corporate Environmental Responsibility: Is a Common CSR Framework Possible? Working Paper of World Bank, 2006.

Mohr, L., Webb, D., \& Harris, K. (2001). Do consumers expect companies to be socially responsible? The impact of corporate social responsibility on buying behavior. The Journal of Consumer Affairs, 35(1), 45-72. http://dx.doi.org/10.1111/j.1745-6606.2001.tb00102.x

Nagar, V., Nanda, D., \& Wysocki, P. (2003). Discretionary disclosure and stock-based incentives. Journal of Accounting and Economics, 34, 283-309. http://dx.doi.org/10.1016/S0165-4101(02)00075-7

Ndemanga, D. A., \& Koffi, E. T. (2009). Ownership Structure, Industry Sector and Corporate Social Responsibility (CSR) practices: The Case of Swedish listed Companies. Master Degree, University of Gothenburg.

Nelson, J. (1998). Leadership Companies in the Twenty-First Century: Creating Shareholder Value and Societal Value. Vision of Ethical Business, Financial Times Management, 1, 21-26.

Norita, M. N., \& Shamsul-Nahar, A. (2004). Voluntary Disclosure and Corporate Governance Among Distressed Firms in Malaysia. Financial Reporting, Regulation and Governance, 3(1). Available from http://www.cbs.curtin.edu.au/files/nasir-abdullah.pdf

Noyer, C. (2008). Les défis de la valorisation dans un environnement changeant. Banque de France, Revue de Stabilité Financière, 12, 1-8.

Ontario Security Commission "OSC" (2002). Improving corporate governance through mandatory social environmental teporting: brief to the Canadian securities administrators on continuous disclosure. Retrieved May 20, 2008, from http://www.osc.gov.on.ca/documents/en/Securities-Category5Comments/com_20020919_51 102_soc-invest.pdf

Reverte, C. (2009). Determinants of corporate social responsibility disclosure ratings by 
Spanish listed firms. Journal of Business Ethics, 88(2), 351-366. Retrieved from http://link.springer.com/article/10.1007/s10551-008-9968-9

Rosenstein, S., \& Wyatt, J. G. (1990). Outside directors, board independence and shareholder wealth. Journal of Financial Economics, 26, 175-92. http://dx.doi.org/10.1016/0304-405X(90)90002-H

Said, R., Zainuddin, Y., \& Haron, H. (2009). The relationship between corporate social responsibility disclosure and corporate governance characteristics in Malaysian public listed companies. Social Responsibility Journal, 5(2), 212-226. http://dx.doi.org/10.1108/17471110910964496

Saleh, M. (2001). Accounting Information Disclosure and Accountability: Cases From Libya. Unpublished PhD Thesis, Sheffield Hallam University, Sheffield, UK.

Shahin, A., \& Zairi, M. (2007). Corporate governance as a critical element for driving excellence in corporate social responsibility. International Journal of Quality \& Reliability Management, 24(7), 753 - 770. http://dx.doi.org/10.1108/02656710710774719

Shamsul Nahar, A., Raihan, N., \& Mokhtar, Z. (2011). Board independence, ownership and CSR of Malaysian large firms. Corporate Ownership \& Control, 8(2). Retrieved from http://www.virtusinterpress.org/IMG/pdf/COC_Volume_8_Issue_2_Winter_2011_Continue d4_.pdf\#page $=63$

Shayuti, A., Chris, S., \& David, H. (2009). Do culture and governance structure influence CSR reporting quality: evidence from China, India, Malaysia and the United Kingdom. SM Adnan. Retrieved from http://apira2010.econ.usyd.edu.au/conference_proceedings/APIRA-2010-271-Adnan-Do-cult ure-and-governance-structure-influence-CSR-reporting-quality.pdf

Shazrul, E. A., \& Mazlina, M. (2013). Corporate social responsibility disclosures and board structure: evidence from Malaysia. Jurnal Teknologi, 64(3). http://dx.doi.org/10.11113/jt.v64.2273

Strandberg, C. (2005). The convergence of corporate governance and corporate social responsibility thought-leaders study. Canadian Co-operative Association. Retrieved from http://corostrandberg.com/wp-content/uploads/files/Corporate_Governance.pdf

Sun, Q., Tong, W., \& Tong, J. (2002). How does government ownership affect firm performance? Evidence from China's privatization experience. Journal of Business Finance and Accounting, 29(1-2), 1-27. http://dx.doi.org/10.1111/1468-5957.00422

Tiling, M. V. (2004). Refinements to legitimacy theory in social and environmental accounting. Commerce Research Papers Series No. 04-6. Retrieved 20 June 2007 from http://www.ssn.flinders.edu.au/business/research/papers/04-6.pdf.

Tsang, E. (1998). A longitudinal study of corporate social reporting in Singapore, the case of the banking; food and hotel industries. Accounting, Auditing and Accountability Journal, 11(5), 624-635. http://dx.doi.org/10.1108/09513579810239873 
United Nations Global Compact's Report (2004). Connecting financial markets to a changing world.

Retrieved

from

http://www.unglobalcompact.org/docs/issues_doc/Financial_markets/who_cares_who_wins.p df

US Report (2011). Investment Climate Statement - Libya: Bureau of Economic. Energy and Business Affairs.

Walker, R (1985). Doing Research: A Handbook for Teachers. Methuen, London.

Weir, C. (2001). Governance structure, director independence and corporate performance in the UK. European Business Review, 13(2), 86-94. ISSN: 0955-534X. http://dx.doi.org/10.1108/09555340110385254

Zairi, M. (2000). Social responsibility and impact on society. The TQM Magazine, 12(3), 172-178. ISSN: 0954-478X. http://dx.doi.org/10.1108/09544780010320278

Appendix 1. Results of Pooled OLS Model

\begin{tabular}{lrrrr}
\hline Variables & Coef. & SE & $\mathbf{t}$ & $\mathbf{p}$ \\
\hline GO & 7.368 & 2.438 & 3.02 & 0.003 \\
BI & -0.121 & 0.154 & -0.79 & 0.433 \\
BS & -0.270 & 0.899 & -0.3 & 0.764 \\
CEO & 7.822 & 3.307 & 2.37 & 0.02 \\
COMS & -0.000 & 0.000 & -1.21 & 0.229 \\
COMA & 0.110 & 0.081 & 1.36 & 0.177 \\
TI & 3.867 & 2.109 & -1.83 & 0.069 \\
R $^{2}$ & 0.28 & & & \\
\hline
\end{tabular}

Appendix 2. Results of Fixed Effect Model

\begin{tabular}{lllll}
\hline Variables & Coef & SE & t & p \\
\hline GO & (omitted) & & & \\
BI & 1.774 & 1.317 & 1.35 & 0.182 \\
BS & 3.304 & 1.207 & 2.74 & 0.008 \\
CEO & (omitted) & & & \\
COMS & -0.000 & 0.000 & -0.69 & 0.495 \\
COMA & 0.712 & 0.225 & 3.15 & 0.002 \\
TI & 0.628 & 2.434 & 0.26 & 0.797 \\
R $^{2}$ & 0.098 & & & \\
\hline
\end{tabular}

\section{Copyright Disclaimer}

Copyright for this article is retained by the author(s), with first publication rights granted to the journal.

This is an open-access article distributed under the terms and conditions of the Creative Commons Attribution license (http://creativecommons.org/licenses/by/3.0/). 